\title{
Exploring the potentialities of the Mexican fermented beverage: Pulque
}

\author{
Zahirid Patricia Garcia-Arce ${ }^{1}$ and Roberto Castro-Muñoz ${ }^{1,2^{*}}$
}

\begin{abstract}
Traditional alcoholic beverages are today recognized for their potentialities and benefits to human health. Pulque is likely to be one of the most consumed traditional beverages in Mexico, which is currently being explored by the research community. Different research and applications have been developed towards the full identification and characterization of the compounds and microbiota presented in pulque. Moreover, to improve its commercialization, specific emerging techniques have been proposed and implemented for the processing of such a traditional alcoholic beverage. Therefore, the goal of this review is to release a comprehensive overview of the latest research and developments focused on exploring the pulque. Herein, a particular emphasis has been paid to the relevant studies and findings in the field. Moreover, a clear overview of the microbial, physicochemical composition, elaboration protocols, together with the main parameters influencing its quality, are given. Few applications and processes aiming for its commercialization have been done (e.g., microencapsulation, spray-drying and ohmic treatment); however, within the exploitation of pulque, its main compounds have been implemented towards the enhancement of properties of other commercial products, such as tortilla and bread. Finally, this review provides the current research gaps and recommendations to the new researchers in the field.
\end{abstract}

Keywords: Pulque, Emerging techniques, Commercialization, Processing, Fructo-oligosaccharides

\section{Introduction}

Pulque is a milky white viscous alcoholic beverage and one of the most ancient and traditional in Mexico, which is prepared in an artisan way and consumed since the pre-Hispanic period. Typically, it is produced by the fermentation of mead, known as aguamiel, which is the sugary liquid (sap) that circulates through the conductive vessels of the maguey or agave; this latter plant generally known as the century plant for English speaking people [1]. Agave is the scientific name given for the maguey. Practically, food and fibers can be obtained from maguey, while from agave can be obtained the distilled beverages, such as tequila and mezcal, in which a great variation of

\footnotetext{
*Correspondence: food.biotechnology88@gmail.com; castromr@tec.mx ${ }^{1}$ Tecnologico de Monterrey, Campus Toluca, Avenida Eduardo Monroy Cárdenas 2000 San Antonio Buenavista, 50110 Toluca, Mexico

Full list of author information is available at the end of the article
}

moisture and temperature are needed for the production of each product.

The production of pulque is confined to Mexico, especially in the central plateau states, where several species of the agave plant, suitable for making this beverage, are found (see Fig. 1) [2, 3]. There were nine genera and 300 species known of agave between 2007 and 2011, of which $A$. atrovirens, A. americana, A. salmiana, and $A$. mapisaga were directly associated with pulque production [4]. The origin of the century plant dates about 10 million years ago, although it may be impossible to track accurately the original forms [2]. Nevertheless, the production of this beverage has led to the domestication of many species leading to phenotypic variation and nonidentification of varieties traditionally used [5].

Due to its great historical, religious, social, medical, and economic importance, pulque has been widely studied from the anthropological to the scientific field [1]. The original author(s) and the source, provide a link to the Creative Commons licence, and indicate if changes were made. The images or other third party material in this article are included in the article's Creative Commons licence, unless indicated otherwise in a credit line to the material. If material is not included in the article's Creative Commons licence and your intended use is not permitted by statutory regulation or exceeds the permitted use, you will need to obtain permission directly from the copyright holder. To view a copy of this licence, visit http://creativecommons.org/licenses/by/4.0/. 


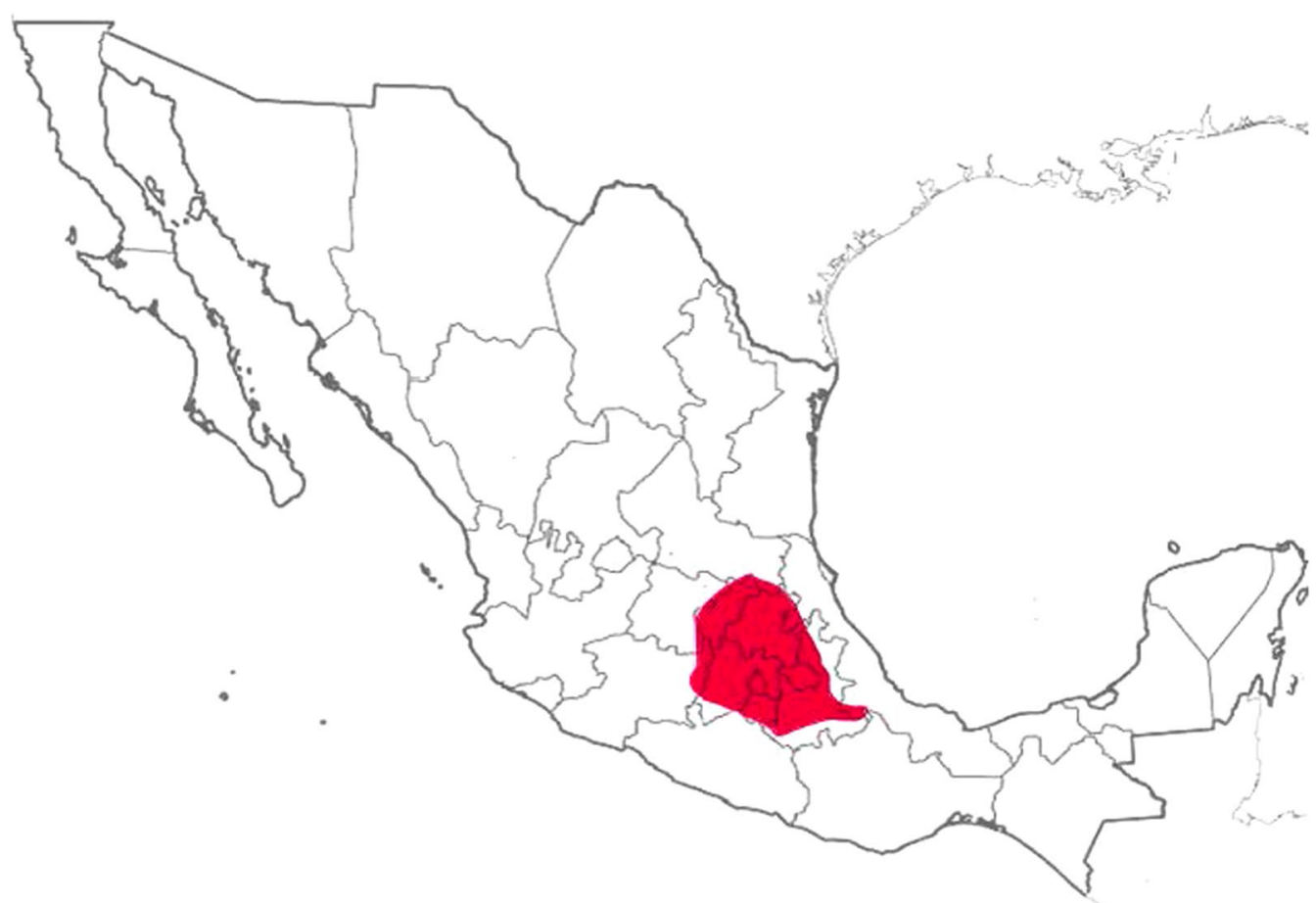

Fig. 1 Central plateau states in Mexico marked in red

beverage was considered as a ritual element that allowed a closer relation with the cosmology of several cultures, such as Aztecs, Toltecs, Olmecs, among others. There is evidence that the Otomi civilization may have been the first one to inherit the preparation process of pulque toward the year 2000 B.C. [4]. However, there is a theory that Toltecs were the first ones, due to different legends that narrate their origin. One of these legends considers the maguey plant as a gift of the goddess Mayahuel, who came to Earth to dance and sing; together with Quetzalcoatl, who was punished with exile after an excessive intake of pulque, they adopted the form of the branches. Nonetheless, they were punished by Mayahuel's grandmother and another darkness being by destroying the branches where they were hiding, hurting only Mayahuel. Quetzalcoatl buried Mayahuel and in such a place the first agave plant grew [1].

In addition, there is pictographic evidence representing the extraction of sap and pulque consumption by the other cultures, but the Aztec culture dominated mead and refined pulque production with different techniques. This beverage was incorporated into their diet and was considered as a divine food and medicine thanks to its nutritional benefits and healing properties [4]. Also, they established the moral guidelines for pulque consumption, immoderate ingestion was not allowed and brutally punished even with the death penalty. Only children, elder and pregnant or nursing women could consume it, while in the case of religious use, priests, warriors, or anyone before sacrifice were only authorized [6]. It is speculated that the ancient Aztecs called to pulque with different names, including metoctli from Nahuatl language (agave wine), iztacoctlli (white wine), or poliuhquioctli (spoiled or rotted wine). This latter name is likely to be the one that the Spanish conquerors used and designated it as the so-called "pulque", the freshly fermented agave beverage [4]. However, when Spanish conquerors arrived and consequently the Aztec Empire fell, pulque lost its religious importance becoming just a traditional beverage. The conquerors took it upon themselves to eradicate Aztec religious, economic and social systems and supplant them with new identities based on Old World ideologies [7]. At the beginning of the colonial period, around the first two centuries, Spaniards did not enter the commercial production of pulque because of the lack of a crowded population capable of buying pulque. Nonetheless, by the mid-eighteenth-century bulk production and distribution, the Spaniards promoted its consumption among the indigenous groups and recent immigrant slaves as a way to control them in Mexico City. The market was in the hands of Spanish residents of the capital, and other members of the capital's elite [6]. These activities gave rise and introduced the development of "haciendas pulqueras", which were large farms specialized for 
the production of the beverage, together with the cultivation of agave plants, extraction of the mead, and the fast growth of the productive and commercial activities [1]. Unfortunately, such activities have been radically reduced over the last 50 years. Nowadays, People own a pulque's perception as a low-class and low-quality beverage. It is now produced and consumed mostly in poor rural areas and primarily by the elderly. Opportunely, its consumption and therefore its production is making a resurgence; it is served by many pulquerías in Mexico City that are frequented by young and trendsetting people [8]. Therefore, the research community is today exploring and studying the potentialities of such a traditional Mexican beverage to foster its commercialization. Hence, the goal of this study is to explore and elucidate recent approaches in pulque processing and application, pointing out the relevant insights and results in the field. Moreover, the nutritional value, protocols and fermentation production processes are also addressed and analyzed to open new gaps for the emerging processing technologies.

\section{Historical, cultural and geographical background}

Agave L. has an important economic, ecological, and cultural significance in Mexico and other regions. Around $75 \%$ of the worldwide agave species are found in Mexico, while approximately $55 \%$ grow exclusively in this country $[9,10]$. The physiological characteristics and morphological conditions of Agave make it capable to adapt to the most hostile environments. These plants can be found from valleys and plains to hills and stony slopes; most of the times being the mainstay in its native environment, providing refuge, food and sometimes water for various organisms, as well as preventing soil erosion $[9,10]$.

According to the experts (e.g., archaeologists, anthropologists, and ethnobotanists), due to its distribution and abundance of over 10,000 years, Agave has been a feedstock of many products, including food, medicines, fiber, construction materials and drinks $[5,10]$. This fact is implied because of the findings including chewed agave fibers in human coprolites and tools encountered in caves inhabited by those who are believed to be the first settlers of the region of the Tehuacán-Cuicatlán Valley. Furthermore, it is believed that the use of agaves for preparing beverages from the extraction of the sap derived from sporadic observations and people imitating animals, who drank that sap of wild agaves excavating holes at the base of their lateral leaves [5].

Codices, the name for the manuscripts painted or written by indigenous people, endorse the link between Mesoamerican cultures and animals eating from the leaves of the maguey. These codices, using encoded images and sometimes text, were used to establish their languages, their manufacturing activities, traditions, and even to argue and defend their rights or privileges. They are considered first-hand sources, written-painted by the protagonists themselves and constitute a valuable heritage for the knowledge of indigenous people. Unfortunately, over the years, the codices left the continent for various reasons. They were spoils of war, gifts to European nobles, or ended with collectors; most of the time illegally taken out of the country [11]. For instance, opossums and rabbits are two of the mammals seen in archaeological remains, codices and facts known and told by the tlachiqueros (people in charge of scrapping the maguey to stimulate the production of mead, then extracted by suction with the help of an ocaxtle) [12].

The rabbit was in allusion to Mayahuel, a deity of the moon and pulque, whose nahual (animal alter ego) was the rabbit. This animal was presented as a dual element that reflected intoxication, transformation, menstruation and pregnancy [13]. Additionally, this mammal was found in pictographs in Veracruz, the iconography of pulque cults was symbolized by naturalistic rabbits carrying a rolled sheet with maguey signs, rabbit-headed creatures with anthropomorphic bodies, and humans with costumes of rabbits [14]. For opossums, marsupial mammals called tlacuaches in Mexico (see Fig. 2), archaeological debris like small clay figurines, whose invoice is estimated around $1000 \mathrm{BC}$, is good evidence to

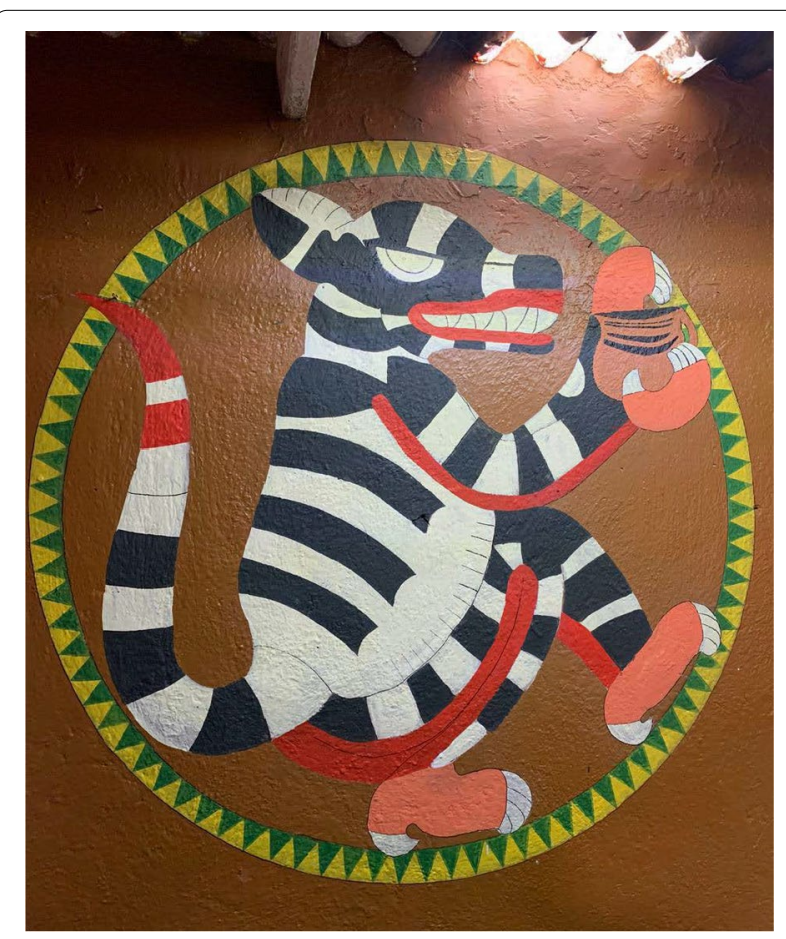

Fig. 2 Typical mural of a Tlacuache representing an opossum painted on the wall of the pulqueria "Tlacua y cuache" in San Lorenzo Tepaltitlan, Toluca, Mexico 
the persistence of its fame [12]. Several codices, including Codex Mendocino and Fejérváry-Mayer (from Aztec codices), Vindobonensis and Nuttall (from Mixtec culture), included calendrical and ritual glyphs; while The Dresden codex from Mayan culture, glyphs associate a weasel with a type a black mask, which was linked to fire, the moon, pulque, fertility and childbirth $[12,15]$. Over time, the animal was loaded with very varied symbols, moreover, being the protagonist of myths, reaching divinization [15]. The opossum is seen as the thief of destinies, concomitant of forces that balance the earth: duality, hot and cold forces. One of the most important myths of the opossum, extremely widespread and rich in variations, is the one that referred to the times when humanity lacked fire and tells how the opossum stole fire from gods to bring it to men. In the same way, the opossum steals pulque, fire and pulque; alternating and divine forces on the surface of the earth. This myth is known for the arrangement of stakes with fire and pulque in the housewarming ceremony celebrated by the ancient Nahuas. A variant of this myth tells that, by stealing the fire, the opossum fails, falling into the fire and causing a fire on the earth, but Mother Earth extinguished it with her own milk, pulque. It also includes that when he falls his tail is burned, and since then his tail is bare. Another myth is that he was liable for stealing corn and pulque, another is the opossum and the Moon complex, which point out pulque as the cold milk of the Earthly Mother, "the refreshing lunar liquid" [15].

Codices show as well when do people were supposed to consume the beverage called at that time "octli poliuhqui". By the argument that immoderate consumption led to an intoxicated state and consequently to lose control and atrociousness, the practice was highly moderated and restricted to certain groups, amounts, and dates with elaborated rituals of consumption [16]. Being alcohol intoxicated was considered improper and a cause for punishment. The Aubin Codex shows that Aztecs could only taste the liquor if they were seniors because it could help them to remember when they were younger, happy and warm, while for the sick and lactating women, it was curative and medicinal power; and for high-level dignitaries, priests, military men, it was used for ceremonies and rituals. The intoxicated nature of octli, as the result of its preparation with roots and condiments, made prehispanic tribes thought as a way of communication with the deities, therefore, pulque was considered as a sacred beverage, along with allowing the warriors to erase any despair, doubt and uneasiness $[12,16]$.

The maguey sap, before fermented, served at that time as a replacement of water during months when there was no rain, which it was called "neutli". This sap is transparent (see Fig. 3) and refreshing; it was initially

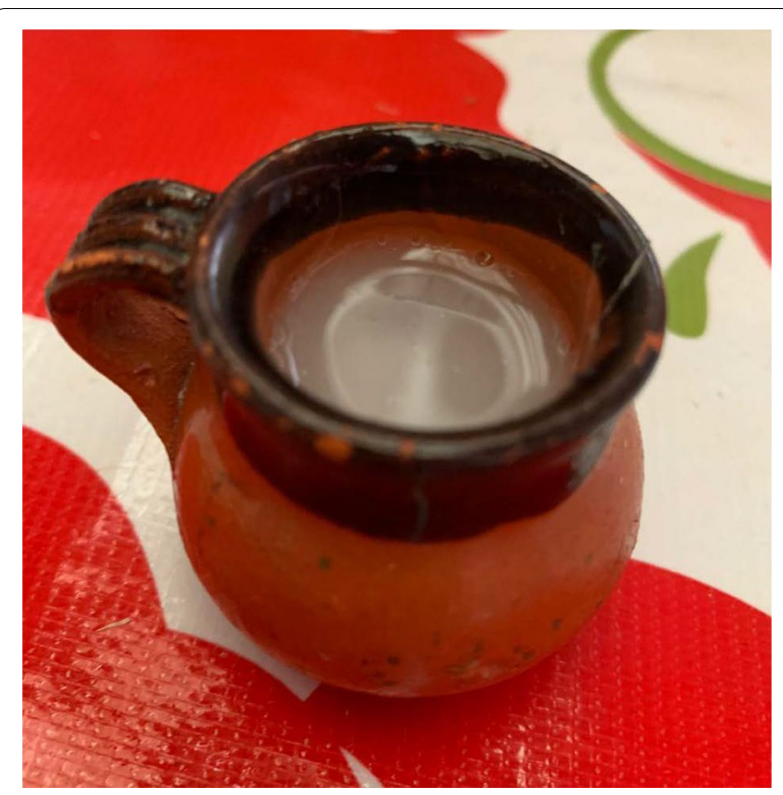

Fig. 3 Aguamiel. Sugary liquid, viscous, semi-transparent called sap hat circulates through the conductive vessels of the maguey

called "aguamiel" after one of the first friars arriving in New Spain. Toribio de Benavente Motolinía thought that it was tasty, slightly similar to honey water that means "agua de miel" in Spanish. Afterward, the Conquest Spaniards started calling the octli poliuhqui, "pulque" and the neutli "aguamiel". Pulque started being of easy access, increasing its popularity among ethnic people. As a result, further supply flooded the market, encouraging even higher demand. Besides, pulque was sold in the streets and squares (well known as plazas) and pulquerias, hence creating cultural mingling, combining the European tavern model, since natives went there for social gathering and leisure time. These factors led to the emergence of urban mass culture, as well as a sense of belonging and identity among these individuals [16].

People enjoyed gathering in pulquerias, which became an integral part of life in Mexico City. Nevertheless, concerns about natives' widespread use of pulque and their inebriation came soon. In 1896, Mexico City had approximately 1761 pulquerias for every 149 inhabitants when the population was on the rise. In the streets, new and old cultural forces clashed, and the structures for preserving order could not keep up with the changes. Alcoholism was a problem since that time, the main cause of alcoholic intoxication cases reported by the Juarez public hospital was pulque. Under the influence of liberalism, Porfirian society, upper class and authorities sought to exert greater control over the population. The goal was to foster a hardworking and moral citizenry. As a result, authorities strictly 
supervised pulquerias' schedules, services, and all activities. Pulque was exposed as a low-quality product, and chemical analysis was even made to uphold its consumption, demonstrating the nutritional and healthy effects as a complement in the Mexican diet; however, consumers were perceived as the most egregious representation of vice's disgusting effects. They drank for hours, emanating foul odors from long shifts at factories, along with theories of adulterer beverage, a mixture of the still fermenting pulque and the patrons' urine and saliva. Drinking in pulquerias was not acceptable for social drinking compared with drinking in cantinas, where wine, cognac and other imported drinks were a sign of good taste [17]. Since these places have been categorized as common expressions of laziness, vice, and loss of discipline, little has been said about them as forms of social coexistence. They are a strong symbolic material of popular Mexico since centuries ago. Several terms, such as the various styles of pulque, cups, ways of drinking it, the music, and games played within, are representations of cultural social habits [18]. Currently, pulquerías have almost disappeared; but only a century ago, people enjoyed gathering there. The judgment to which pulque and pulquerias have been subjected by different organizations and Mexican culture have led to their devaluation, as they are now discredited and considered a source of societal disdain. As a result, the decrease of the maguey cultivation in central Mexico has resulted in a major reduction in pulque output. Despite this fact, there are still a few establishments in the region that market and give a positive reputation to the drink.

Cultural tourism has been the strategy for the movement with the aim to know, understand and enjoy the spiritual, traits and elements of the beverage. Few actions have been carried out to take advantage of pulque and pulquerias as tourist resources. The objective is to promote and disseminate the gastronomic heritage, such as cured pulque known as "pulque curado" [3]. Here, the drink is prepared with fruit, seeds, and cereals, such as oatmeal, to provide it flavor and a different experience when drinking it. In particular, it has been shown that pulque is a gastronomic heritage of the city of Toluca in the State of Mexico; although it is not produced entirely within the municipality, there is consumption among the local population and tourists, highlighting that young people, between 18 and 33 years old, are most interested in consuming it and attending the pulquerias [3]. "Tlacua $y$ cuache $^{\prime \prime}$ is a clear example of a pulqueria in the city, as illustrated in Fig. 4. It is located in San Lorenzo Tepaltitlán town, where people prepare cured pulque based on different flavors, such as mamey, red fruits, oats, peanuts, beets, piña colada, among others (see Fig. 5). It is worth mentioning that the owner, Nayib, opened the spot towards promoting social coexistence and share his passion for pulque in his town.

The study of beverages, like pulque, is considered necessary and convenient to help the study of popular culture in Mexico [18]. Food is an important component of social and cultural processes. It can generate social relationships and alter aspects of daily life, such as power and prestige, along with serving as means of social control [19]. Beyond traditions and customs, the conception of spaces, as places of practical and symbolic use within society, can determine identity as well. This can foster the strengthening of identity in a study region and contribute to the explanation of understanding and appreciation of the past [20].

\section{The biochemistry of the Pulque: artisanal preparation protocols and their influence on the physicochemical and microbiological properties}

Pulque is a non-distilled alcoholic beverage, which presents an alcohol content between 4 and 7 in Gay-Lussac degrees [21]. The process of pulque production has almost persisted without any change throughout the years, in general, the preparation of many indigenous fermented foods and beverages remains today as artisanal work, but there is not much verified data about indigenous fermented foods and drinks neither about their nutritional and quality control attributes [22]. Particularly, pulque production has been affected over the years, for example, during the independence movement between 1810 and 1821 in Mexico, and later in the revolutionary movement (in 1910). In addition to this, it was affected by political regulations for agricultural activities, land redistribution, the new constitution in 1917, and the social instability together with the introduction of the brewing companies [1].

Despite it has not reached international nor local massive production, pulque still remains as a traditional artisanal alcoholic drink as a part of Mexican culture. This alcoholic drink is produced in homes, villages and smallscale industries since it has great relevance in the daily life of indigenous communities [1,23]. Its production at a small-industrial level gives the beverage an opportunity to be canned and exported facilitating the quality control in the process and safety of the product [23, 24], but the product should be fast consumed since it displays a shelf life between 1 and 3 days. To date, there have been diverse attempts to obtain a sturdy bottled/canned product with long shelf life, good quality and hygiene since the twentieth century. Interestingly, the first pilot plant was established in the $60 \mathrm{~s}$ for pulque production from pasteurized mead, among other facilities capable to produce 

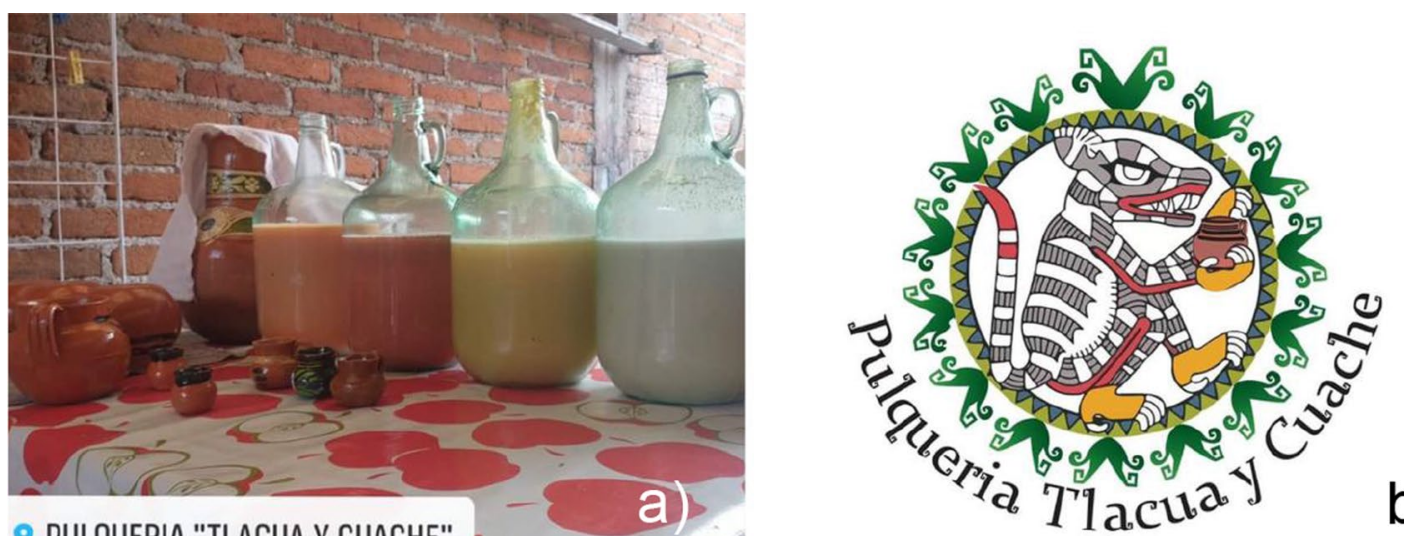

b)

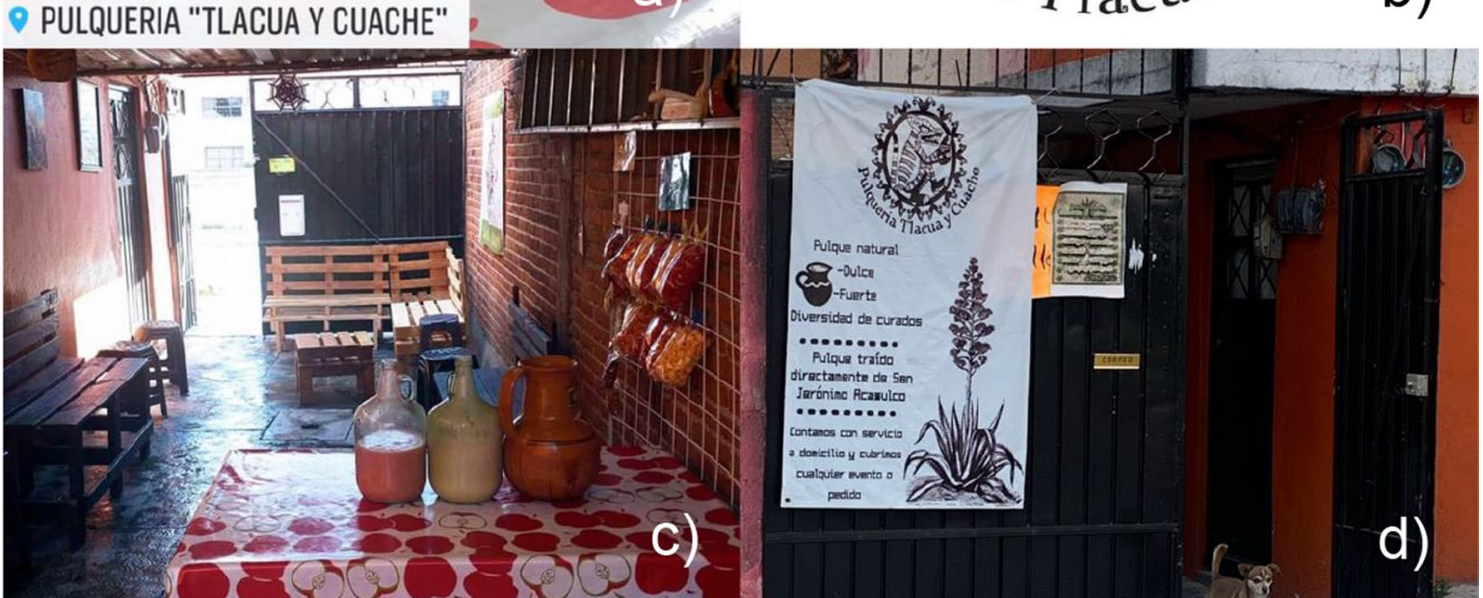

Fig. 4 Pulquería "Tlacua y cuache" in Toluca. a Pulque curado based on different flavors, such as mamey, strawberry, piña colada and oats. The pulque is served in clay cups for drinking at the moment and served in a plastic bag to take away. b Logo of the pulquería, which shows an opossum with a cup of pulque and maguey figures around. c Overview of Pulquería "Tlacua y cuache" where pulque is consumed and sold. d Pulqueria entrance that seems to be a normal house entrance in San Lorenzo Tepaltitlán

up to 50,000 L; however, several difficulties in its preservation were presented causing the plants to close. Also, in Tlaxcala (Nectar del Razo) and Puebla (Desarrollo Agropecuario del Altiplano), two companies have exported a canned product from modifications to the traditional process to make it more stable $[1,23]$.

Meanwhile, until bigger markets can be reached, pulque is found in its pure form (natural) or cured, which is prepared based on white pulque blended with macerated fruits, cereals, grains, nuts, vegetables, among others [24]. The characteristics of natural pulque are a herbal aroma, viscous liquid consistency, white color and slightly acidic since its $\mathrm{pH}$ range ranged from 3.5 to 4.2 $[4,25]$. Pulque properties indeed depend on the primary raw materials, such as nectar produced by the maguey, and the sap. The sap or mead is a translucent liquid with high content of sugars, identified as fructans, sucrose and glucose. Nectar displays a basic $\mathrm{pH}$ of 7.5 and is extracted from young maguey when they are around 4 to 6 years old [25]. As stated previously, the drink is obtained from the fermentation of the sugars, this process begins in the maguey thanks to the microorganisms forming part of the native microbiota of the plant. The chemical changes due to this process develop the growth of various microbial groups, including yeast and bacteria, along with the production of ethanol and exopolysaccharides [26].

Even if Mexico has more than 200 fermented edibles and drinks from 3500 worldwide, they have been hardly studied [27]. It is known that fermentation is one of the oldest processes and can be attractive or either undesirable for us as consumers. Herein, food serves as a substrate for microorganisms, in which their enzymes, such as amylases, proteases, lipases, among others, hydrolyze macromolecules into other products with characteristic flavors, aromas and textures. Such resulting biomolecules can be rather pleasant or unattractive, but even toxic or disease-producers to the humans. Fermentation can also be used for food preservation since it allows to preserve the nutrients, including vitamins and amino acids, and it is cheaper than the cost of freezing or canning the 


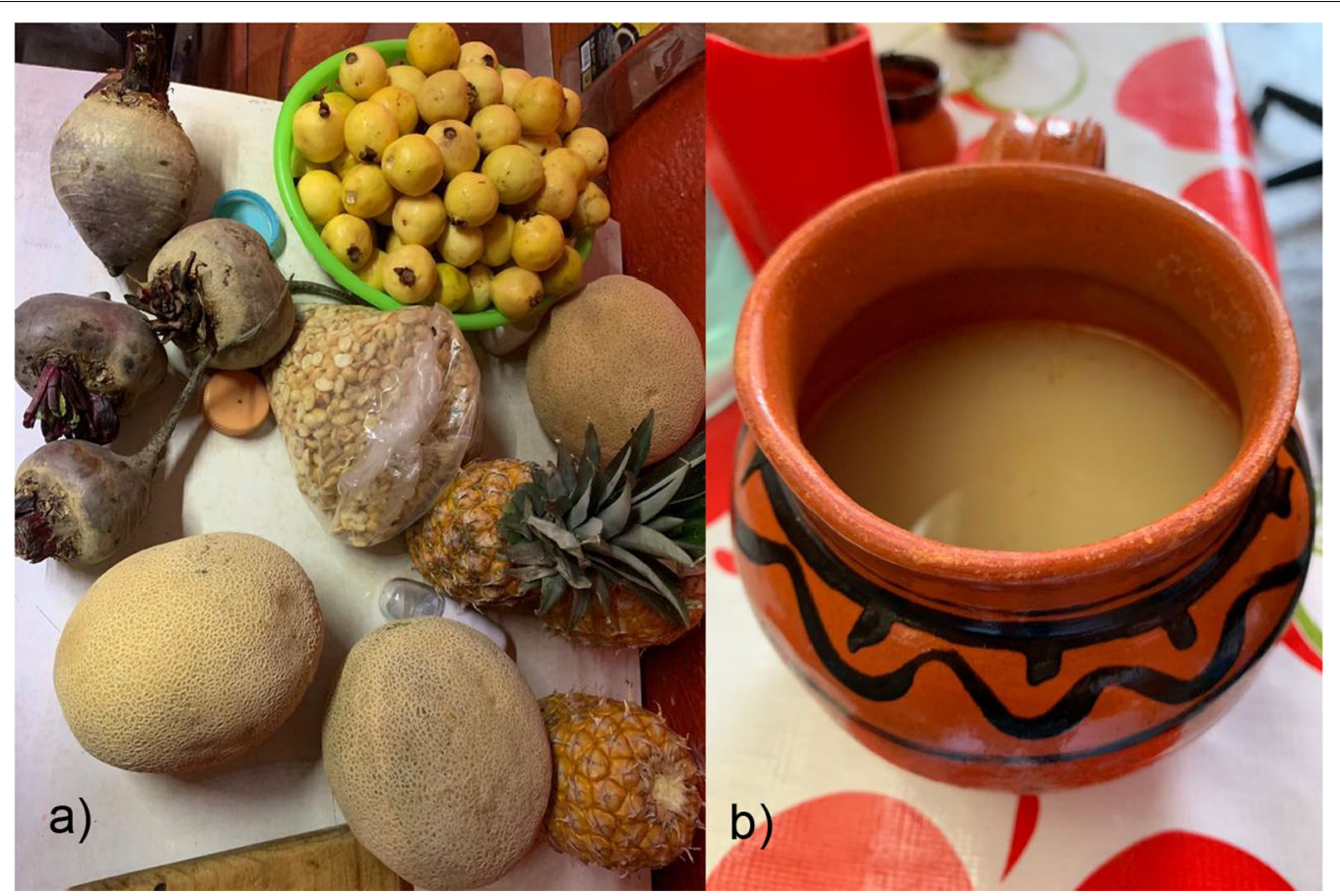

Fig. 5 Fruits used for cured pulque and a cup of pulque. a Fresh fruit used in the "Tlacua y cuache" pulquería for preparing cured pulque, including guavas, melon, pineapple, peanuts and beets. b Clay cup of pulque piña colada flavored

stock to extend its shelf-life. Furthermore, consumers can obtain a significant amount of nutritional molecules through fermented foods and beverages [28]. Fermentation, either in small-scale industries or in home-produced stocks, is one of the first steps for scaling-up a process. To achieve the industrialization of a beverage, microbiological characterization is important since it allows the identification of the essential microorganisms [4]. The origin of these microbes can be from the native microbiota of the food or can be from an independent starter [27]. In the case of pulque, fermentation is an uncontrolled process performed by both natural microbiota, as well as the microbes in a starter, using a fed-batch procedure. For this, aguamiel is added to a container, which is made of wood, clay or plastic, to maintain a constant volume, afterward, fermentation produces pulque, which is generally withdrawn until consumption $[8,29]$. This process takes around 8-30 days, depending on temperature and the climate [30]. Although the degree of fermentation varies, the producer tends to stop the process when certain characteristics, such as alcohol degree, texture, color, viscosity, are reached [1].

The fermentation degree of pulque can be determined by studying its viscosity, which is directly related to exopolysaccharides synthesis and alcohol content. All the process is made at antiseptic conditions, which means that apart from the natural microbiota of the mead, other microorganisms are accumulated during the harvesting, transport, inoculation and the manipulation of this beverage [31]. Some studies have revealed a great variation in the types and quantity of microbiological cultures isolated from pulque, including lactic and acetic acid bacteria and yeasts, e.g., Saccharomyces spp., which may be present in stable mixed populations $[8,23]$. For instance, Valadez-Blanco and co-workers determined tremendous variability in the types and quantity of the indigenous microbiota but always containing lactic acid bacteria ranged from $6 \times 10^{7}$ to $2 \times 10^{11} \mathrm{CFU} \mathrm{mL}^{-1}$. Such variability was related to the conditions of the places where the pulque was prepared [8].

The traditional process starts with the selection of mature plants to be castrated, some authors state that the aguamiel can be extracted from a maguey plant between 8 and 10 years old, while others determine that the plant can be used since early 7 years old $[1,32]$. The castration is usually performed in spring or autumn, it involves the destruction of the flower and the leaves around the plant. Basically, the lesion created from the removed floral stem has a circle shape in the maguey center. In this cavity, the so-called cajete, maguey excretes and keeps the sap, in which nectar collection takes place. Some producers leave the cavity for up 12 months until the leaves and the mead can mature. Then, by using a sharp tool, the so-called ocaxtle, the walls are scraped to provoke sap 
production, where the vessels are kept open and a constant aguamiel flow is maintained $[1,4,33]$. Practically, there is a twice-daily collection of the nectar by oral suction with an "acocote", which mainly a wood-based container, but it can also be made of clay or plastic. Every extraction will result in 6 to $8 \mathrm{~L}$ of mead, and the production of the nectar will be from 3 to 6 months or until the maguey plant dies, and it can reach a production up to $1000 \mathrm{~L}$ per plant [1].

Mead fermentation begins in the cajete, displaying a very slow rate; after this, the fermentation process is carried out in open vats of leather, wood, masonry, or fiberglass. The time of the process depends on various factors, such as the season, aguamiel quality, time of castration step, influencing overall pulque production. In addition to this, if a pulque starter is used, its maturity and the seed microbiota also affect the process [32]. Pulque starter is generally used to optimize the fermentation within the preparation of the beverage by raising the microbiological load [23]. This seed pulque used in a fed-batch process and it is a protocol that may result in lower cost; importantly, it usually takes around $72 \mathrm{~h}$ for fermentation, which seems to be enough time for the growth of the main microorganisms, including yeasts, lactic acid bacteria, ethanol-producing bacteria, and exopolysaccharide-producing bacteria. After the inoculation with the starter, the nectar tends to ferment into pulque within the first 24 up to $48 \mathrm{~h}$ at $16-30{ }^{\circ} \mathrm{C}$ [25]. For instance, Fig. 6 illustrates a graphical drawing showing the basic steps of the process, including plant castration, scraping and extraction of mead, the preparation of the seed pulque, the fermentation and the final product.

Over the years, initiatives and improvements have been made to the elaboration process. Producers have adapted their tools and experience to simplify and optimize pulque production. For instance, Carbajal [34] registered a patent for the elaboration and preparation of pure and clean pulque, which implied a filtration step of the unfermented mead under pressure, avoiding contact with air as much as possible. After this, a heating protocol on the

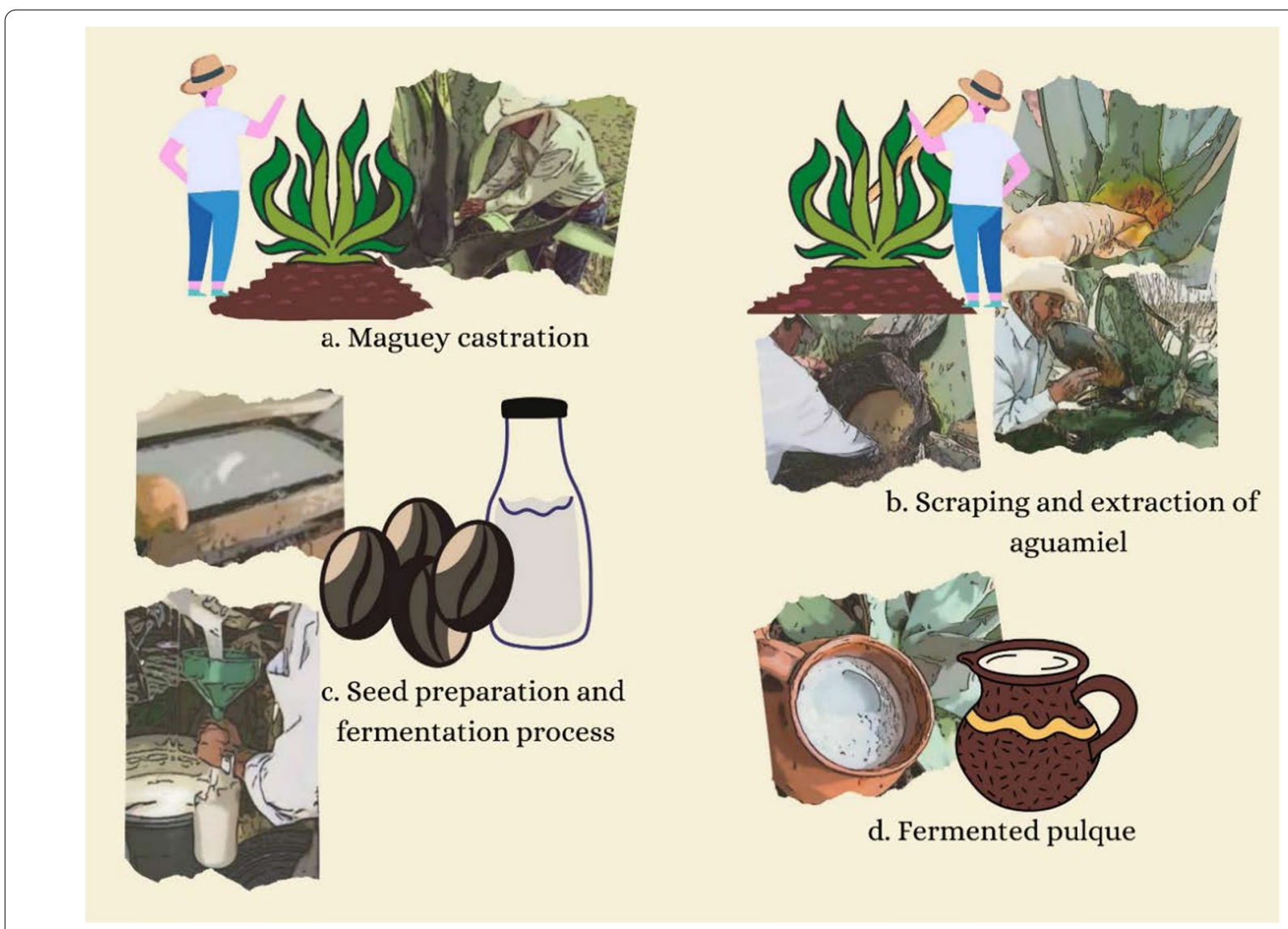

Fig. 6 Pulque elaboration process. a Once the plant is mature enough it is castrated by cutting the floral bud. b With the help of a pit, scraping is performed to promote the production and accumulation of the mead, being later extracted. $\mathbf{c}$ The seed pulque is prepared, and the fermentation process starts due to the microorganisms contained in the mead. $\mathbf{d}$ The final product, the fermented mead, can be prepared and blended with fruits for different flavors for improved sensorial property. Adapted from Escalante et al. [4] 
filtrate to obtain a syrup was proposed, which was followed by adding a pure yeast of Saccharomyces againica to carry out the alcoholic fermentation [34].

To date, there is no standard procedure for the microbial fermentation process; however, there is a Mexican regulation since 1972, NMX-V-037-1972 "Official Mexican standard for pulque handled in bulk by the Bank of Mexican Standards" [35], which helps to define and establish the desirable organoleptic and physicochemical properties of pulque in bulk for direct consumption [4]. Table 1 enlists the characteristics for two types of pulque, in general, the variability of pulque's quality and stability depend on its production, including all the process from the composition and species of the maguey plant, cultivation conditions, the season of the year, humidity, and soil properties to the degree of fermentation, as well as its distribution [1]. In theory, pulque type I, recognized as pulque de semilla, refers to the starter used to increase the microbiota for the fermentation process; and type II is typically identified as the commercial one [23, 35]. Nonetheless, producers classify traditional pulque type I, named as white or fine, and type II as tlachique [4].

\section{Functional properties of Pulque}

Despite it is has been documented that high and excessive consumption of alcoholic beverages may cause different types of diseases, including pancreas cancer, pancreatitis, hepatitis, fatty degradation of the liver, cirrhosis, peptic ulcers, allergenic induction, among other derivative harmful effects [36], alcohol consumption takes an important role in Mexican culture, in which drinking alcoholic beverages is a valued part of social life [24]. Beyond the culture, alcoholic beverages incorporate a significant part of diets, and not only in Mexico but all over the world, reaching $10 \%$ of energy intakes in industrialized countries. In addition, micronutrients of great importance, such as vitamins and minerals, have been associated with the consumption of fermented beverages, like pulque [37]. While in Prehispanic times apart from nutrients, it was also an important source of potable water. Pulque can contribute to the consumption of micronutrients to the diet of people who live in marginal areas in undeveloped countries [38].

This alcoholic drink has been considered as nourishing in moderate consumption since it is not distilled nor over-processed. It can provide significant amounts of ascorbic acid, iron, riboflavin, steroidal saponins, in which many of them display bioactive properties. The medicinal features of pulque may be presented by saponins, which have shown hypocholesterolemic, anti-inflammatory and antibiotic activity [38]. There is evidence confirming the existence of diverse important amino acids in mead, such as arginine, aspartic acid, alanine, valine and methionine; as well as a microbial and enzyme variety [39]. The fermentation process may also develop the growth of different microorganisms since the beginning in the mead, along with transport, manipulation and collection, it does not take place under aseptic conditions [40]. In addition, since there is a great interest in studying fermented food as a potential source of probiotics, the research towards pulque and aguamiel has been mainly focused on its identification and characterization of their enzyme and microbial variety [41]. Since 1965, the term "probiotic" was introduced to describe the microbial material that stimulates the growth of other microorganisms or tissues. The meaning has evolved over time to a live microbial substance that benefits the host animal by improving its intestinal microbial balance [42]. Until 2002, the WHO (World Health Organization) defined probiotics as those microorganisms that administered in adequate amounts confer a health benefit to the host [43]. Every host body has a composite population of different microorganisms, known as intestinal microbiota. These compelling different bacterial species contribute to the health of the host by boosting the integrity of the epithelial barrier and the promotion of mucosal immunity when administered in adequate amounts [44]. In order to provide health benefits and have immune

Table 1 Quality specifications of two types of pulque*

\begin{tabular}{|c|c|c|c|c|}
\hline \multirow[t]{2}{*}{ Specifications } & \multicolumn{2}{|l|}{ Type I } & \multicolumn{2}{|l|}{ Type II } \\
\hline & Minimum & Maximum & Minimum & Maximum \\
\hline Refractometric degree (refractometer immersion) at $20^{\circ} \mathrm{C}$ & 32 & 34.5 & 25 & - \\
\hline Refractive index (refractometer of immersion) at $20^{\circ} \mathrm{C}$ & 1,3390 & 1,3406 & 1,3365 & 1,3380 \\
\hline $\mathrm{pH}$ & $>3.7$ & 4.2 & 3.5 & 4.0 \\
\hline Total acidity (lactic acid) g/100 ml & 0.40 & 0.75 & 0.40 & 0.70 \\
\hline Total reducers (glucose) g/100 ml & 0.10 & 0.80 & 0.20 & 0.50 \\
\hline Alcohol content $\%$ of alcohol by volume & 6 & 9 & 4.0 & 0.6 \\
\hline
\end{tabular}

* Adapted from Salud Publica de México, Legislación, Norma oficial mexicana para el pulque manejado a granel, NMX-V-037, p. 845, Época V, Volumen XIV, Número 6. 30 de septiembre de 1972. Available at [35] 
functions, the probiotic strains must be resistant to certain conditions as the gastrointestinal ones; their efficiency must also be confirmed and cataloged as safe with human studies [41].

The effect of the use of probiotic strains encompasses a microbial feed boost that will benefit the host living being by improving its intestinal microbial equilibrium [42]. The concept is applied to the evidence that the microbial gut helps human physiology, contributing to treat and prevent several diseases, such as traveler's diarrhea and inflammatory bowel diseases (IBDs) [45]. Despite this, features on probiotics usage have been described before 1999 including the production of $\beta$-galactosidase, which improves tolerance to lactose, prevention of recurrent intestinal infections by microorganisms (e.g., Candida spp). Herein, there are several attributed mechanisms, such as competition for nutrients, secretion of antimicrobial substances, blocking of adhesion sites and toxin receptor sites, among others. Furthermore, epidemiological studies have also suggested the suppression of a carcinogen or procarcinogen. In theory, the suppression of bacteria with enzyme activities may convert procarcinogens to carcinogens and stimulation of the immune system among other mechanisms, e.g., probiotics can suppress cancer $[40,42]$.

Thanks to research, the knowledge of human health and disease treatment is increasing. For example, some studies have demonstrated that probiotics could help in preventing coronary disease by holding the cholesterol absorption from the gut, affecting directly its concentrations [42]. However, the research in this field is still limited to classical probiotics. The studies of the human gut microbiome, concurrently with advances and new information of probiotic strains, are based on epidemiological analysis that will provide remarkable conclusions to establish novel generations of probiotics and their role in human health. This also contributes to efficient strategies to facilitate its consumption since they should be administrated in a safe way when consumed in foods and food supplements [43, 46].

Considering the importance of probiotics in health, there is great interest in studies on fermented food products, like pulque, as a way to acquire the new generation of probiotics [41]. At the same time, the functional effects of pulque have been of interest to the scientific community over the last years, in consequence, numerous studies have been carried out for the investigation of the probiotic effects of this beverage. Additional file 1: Table S1 reports some studies aiming to isolate and characterize different strains from pulque, together with prebiotics, and thus evaluate their probiotic effect. Different species of agave were studied from different regions of Mexico, and also the characteristics of aguamiel over different harvest seasons [39]. Herein, different assays were carried out, e.g., Torres-Maravilla et al. [45] studied different strains obtained from pulque and subsequently evaluate their potential as probiotic isolates. They tested the adherence of the strains to gut epithelial cells, also their immunomodulatory properties using a mouse model by evaluating its weight loss, monitoring their gut permeability and cytokine modulation [45].

Together with probiotics, prebiotics are also important since they play the role of foods (usually high in fiber) that act as nutrients for the human microbiota. Such bioactive compounds have been investigated in detail; for instance, Ortiz-Basurto et al. [39] and Castro-Zavala et al. [47] reviewed fructose polymers (i.e., fructans) and their implementation in foods. These non-reducing sugars are commonly used as food ingredients since they are ingredients of specific products, such as ice cream, yogurts, in which there is a target of replacing the fat [39]. Fructans have displayed several benefits to health, and compensating the ravages of various diseases, such as irritable colon syndrome and ulcerative colitis. Furthermore, according to the FDA (Food and Drug Administration), fructans are recognized as GRAS (Generally Recognized as Safe) additives, it means, they can be used freely in food formulations [47]. Their use as prebiotics has been recently regarded since they are not directly digested in the stomach and they can reach the colon without degrading and hence they can stimulate bacterial growth serving as fermentative substrates [39]. The difference between a probiotic and a prebiotic relies on that the last one is a "non-digestible food ingredient", while a probiotic refers to a live microorganism. Besides, prebiotics can also have a therapeutic effect on the host. This is because it allows the growth and stimulates the activity of specific microorganisms in the colon. Of course, a prebiotic has to satisfy certain requirements, such as resist gut conditions, gastrointestinal absorption, stimulation of microbiota growth, among others [48].

Unlike the positive benefits of pulque compounds, some studies have also discovered pathogenic strains in pulque, for example, eight different strains of Bacillus spp. were isolated by González-Vázquez et al. [49], who showed that every strain of this gram-positive bacteria was resistant to at least one antibiotic [49]. Likewise, Gomez-Aldapa et al. [50] found some derivative strains of $E$. coli that were acid and alcohol resistant, and also capable to multiply and survive during several fermentation cycles, which are non-desired in pathogenic microorganisms [50]. Since they were isolated from pulque, this could present a health risk for consumers not only for adverse effects of ethanol but also from the microbiological perspective. Importantly, there is no evidence about other indigenous pathogens' presence in pulque, 
such as Salmonella spp., Staphylococcus spp. and Listeria spp. Consequently, this is considered an advantage since pulque is typically produced in an artisanal and poor hygienic conditions [25].

\section{Current practices in Pulque processing}

It is notably recognized that multiple technological advances in the food industry have been presented in recent years; innovations and new products come to the market every year. Regardless of such advances, the pulque production maintains the artisanal process; the producers usually run family business and tradition. The beverage is mainly sold in "pulquerias" and sometimes in producers' houses, these types of establishments are legally regulated and sold. However, there are some other establishments, like street markets, without any regulation but necessary for its distribution. Blas-Yañez et al. [51] have studied the sociological aspects of the pulque industry, showing how indigenous communities have displaced to cities to sell their product and thus improve their economic status. However, the process of transportation affects the storage of the product, as well as its characteristics and flavor [51].

Despite pulque as a product has not changed, some other processes have been proposed for the improvement of its properties, probiotic/prebiotic effects, and nutritional value. For example, Alcántara-Zavala et al. [52] studied the application of an emerging technology, such as ohmic heating, to extend the shelf life and retain the physicochemical, microbiological, and sensory properties of pulque. The authors established, for the first time, this technique to treat the beverage. Shelf life was in fact extended upon 22 days with steady physicochemical properties, including $\mathrm{pH}$, color, sensory acceptance. Microbiological properties were also maintained, together with a high content of lactic acid bacteria (Lactobacillus acidophilus, Lactobacillus kefiri, and Saccharomyces cerevisiae) compared with the conventional pasteurization process [52].

In addition to expanding the market and production of this traditional beverage seeking the extension of its shelf life, other emerging techniques have been attempted as potential candidates for processing, e.g., microwaveassisted technique. For industrialized products, quality control is needed, and this technique can be used as a method to regulate the process. Over the years, fermented drinks, including beer, wine, whiskey, and even Japanese sake, have been studied reporting their dielectric characteristics, but the processing of pulque has not been reported. Kataria et al. [53] found and established that microwave techniques could be used as quality control methods, or as pasteurization aids for fermented drinks, where their dielectric characteristics must be well-identified. Knowing the dielectric characteristics of foods is of great importance for industrialized processes, and it would be necessary if traditional pulque methods will be translated to an industrial level [53].

Since pulque consumption has been related to beneficial effects for health, research is becoming important for the new progress in the potentialities of the beverage. Definitely, probiotics and prebiotics play an important role in health and disease prevention, where their implementation in foods is gaining recognition. At this point, lactic acid-producing bacteria are the most common probiotic in foods (e.g., dairy products) [54]. In the light of research and characterization of the microbiota presented in pulque, Riveros-McKay et al. [55] published a draft of the genome sequence of $L$. mesenteroides strain P45 isolated from a controlled pulque fermentation. Interestingly, chromosomal DNA was extracted and sequenced by means of Genome Analyzer IIx (Illumina). This important finding was carried out at the University Massive DNA Sequence Unit, of the Biotechnology Institute at the Universidad Nacional Autónoma de México. Their project was deposited at the DDBJ/EMBL/GenBank database, providing valuable information on the properties of this Mexican drink [55].

In recent years, the interest has grown in other derivative products that can be obtained from pulque, which present promising potential as a feedstock for other processes and products, for example, inulin as a plant-based polysaccharide. This contains glucose and fructose that can be used in the food industry as an additive, inulin hydrolysis liberates fructose syrups that can compete as a sweetener with high-fructose corn syrups. In addition, it can be used in industrial fermentations as a substrate [56]. Taking this into account, the production of inulin or inulinase, as the enzyme that catalyzes the hydrolysis of inulin, is a promising area of exploration. Cruz-Guerrero et al. [57] studied strains of Kluyveromyces spp. isolated from aguamiel and pulque for inulinase hyperproduction. The result obtained with these two strains was 2.5 times more enzyme than a control hyper-producing strain K. marxianus CDBB-L-278, and they also showed lower catabolic repression [57]. This is a starting point in the exploration of derivatives and components of the beverage for industry rather than the beverage itself.

Table 2 reports several studies focused on the use of pulque and its by-products. Hernández-López et al. [58] used starch pulque as wall material to produce microencapsulated Lactobacillus pentosus. The encapsulation was done by using spray-drying, which was aimed at optimizing and obtaining the maximum viability of the probiotic. Within this technique, microencapsulation provides a physical barrier to the live probiotic cells for protection against environmental adverse conditions. Spray drying 


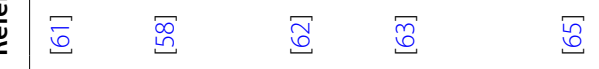

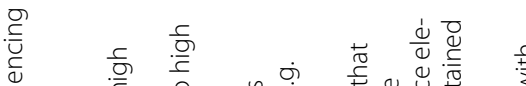

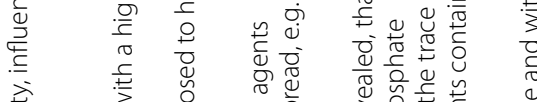

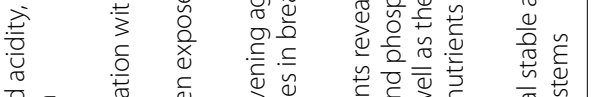

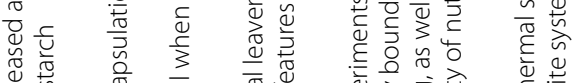

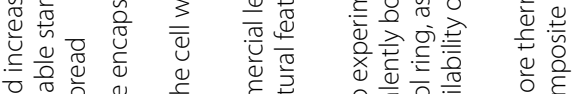

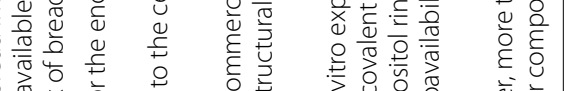

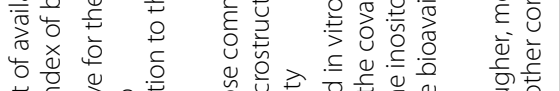

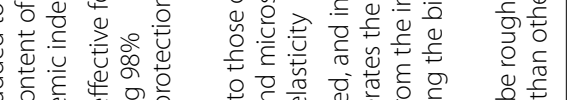

ర원

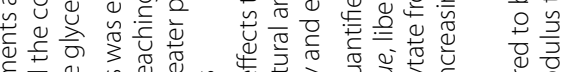

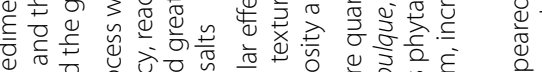

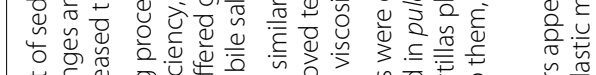

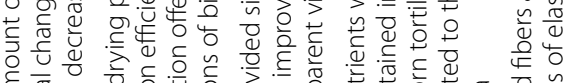

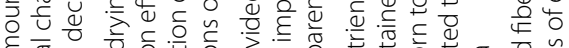

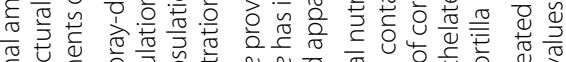

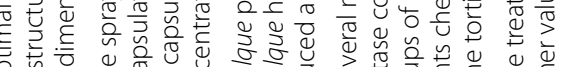

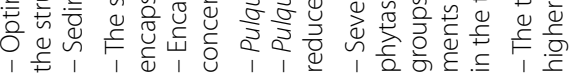

$\begin{array}{ccc}\frac{1}{3} & \frac{2}{0} & \frac{0}{0} \\ \frac{1}{3} & \frac{0}{0}\end{array}$

$\frac{\sqrt{5}}{0}$

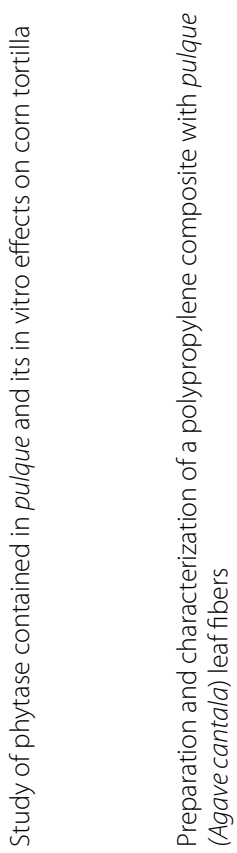

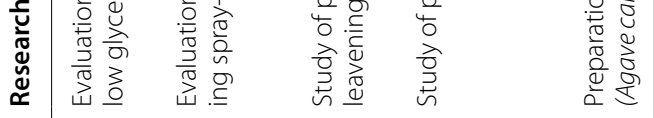

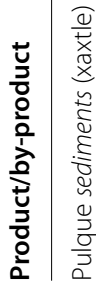

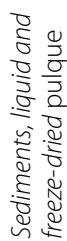

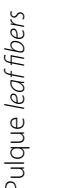


is a fast and cost-effective drying method to produce spherical powder particles for ready-to-use products (e.g., prebiotics, probiotics, nutraceuticals, bioactive and thermolabile compounds) [59, 60]. Microencapsulation is a relatively novel technique that has an approach to improving cell survival during processing, storage, and consumption. Its use in probiotics lies on the survival of microorganisms until its consumption during the processing and shelf life of the food or supplement, and after its consumption in the acidic conditions of the stomach, as well as basic conditions of the bile salts in the small intestine [58].

The food industry is evolving, and the use of waste materials as a new feedstock in new processes and products is gaining interest. Some Mexican products, such as bread and tortilla, have an artisanal production process as pulque. Over the last years, some authors have studied different by-products of pulque to produce bread and tortilla [61-63]. Tovar et al. [63] studied lyophilized pulque and sediments for producing tortillas with higher nutrient value. Considering that in most of the rural and marginal areas the consumption of selenium, vitamin $C$, zinc and iron are deficient based on the low intake of animal foods, pulque and tortilla could be meaningful sources to face the ameliorate iron and zinc deficiencies in the rural areas in Mexico. Therefore, phytase contained in the beverage could also be a promising additive to a traditional and daily-consumed product, like a tortilla, in order to increase the bioavailability of the nutrients mentioned previously [63].

\section{Concluding remarks and recommendation for the new researchers in the field}

Pulque is a non-distilled alcoholic beverage and originally from Mexico, which has an alcohol content between 4 and 7 in Gay-Lussac degrees [21]. This traditional Mexican beverage has a milky white viscous consistency and it is produced by the fermentation of mead, a sugary liquid, that circulates through the conductive vessels of the maguey plant [1]. Thanks to its physicochemical compositions and native microbiota, it is still produced and consumed since the pre-Hispanic period in Mexico until nowadays. To date, some studies have demonstrated that pulque contains probiotics (generally lactic acid bacteria) and prebiotics, mainly fructooligosaccharides (FOS), which may contribute to prevent coronary disease by holding the cholesterol absorption from the gut, affecting directly its concentrations [42]. Recently, the functional effects of pulque have been of interest within the scientific community, in consequence, numerous studies have been carried out for the investigation of the probiotic effects of this beverage, along with the identification and characterization of such native microbiota. Herein, bioinformatics could be of great help to design new probiotic formulations to reduce inflammatory and diet-related disorders [46]. Unfortunately, there is still a long gap of information needed for future applications and the industrialization of the pulque production process. For this reason, precise knowledge of pulque as a source of nutrients and additives for other traditional Mexican foods is required. Importantly, there is a growing interest in the rich diversity of yeast and lactic acid bacteria present in this beverage contains. Nevertheless, many authors have pointed out the evidence of the potential of the drink and the development of the next-generation products, such as probiotics, nutraceuticals and functional foods [61-63]. When dealing with the exploitation of pulque and its byproducts, pulque sediments have proved to display a high concentration of nutrients contained in the drink. Such sediments have been already used in the enrichment of tortillas and bread which not only improved their nutritional value but their texture properties as well.

Regarding the processing of the pulque, new emerging techniques, such as ohmic heating, microencapsulation and spray-drying $[52,58]$, have been applied with the aid of extending the exploitation of pulque. Herein, the current review identifies a wide lack of investigating and applying other different techniques for the processing of such a beverage. Therefore, relevant recommendation for further processing of the product are given:

- The separation and recovery of FOS as potential prebiotics can be a new research gap. Considering the molecular weight of such compounds ranged from 504.43 to $828.72 \mathrm{~g} \mathrm{~mol}^{-1}$, tight ultrafiltration and nanofiltration membranes are promising candidates for the separation and even concentration of such compounds and thus extend their application in food technology, as well as new food and pharmaceutical formulations.

- Today, it is well known the harmful effect of alcohol consumption, therefore, there is a current trend in producing non-alcoholic beverages, where the removal of the ethanol after fermentation is the desired pathway to skip any loss in sensorial properties of the beverage [64]. Here, a highly selective membrane technology, like pervaporation, has been nowadays proposed for the dealcoholization of beverages as a promising alternative to produce nonalcoholic drinks [36, 64], which can also maintain most of the organoleptic and nutritional values of the original beverages. To date, there is no report in dealcoholizing the pulque.

- Finally, it is widely known that pulque is a typical Mexican drink that is mainly consumed and commercialized in Mexico, however, food technicians 
should start the development of suitable packaging materials for extending the commercialization of this valuable drink, which definitely can reach a potential success in foreign countries similar to other Mexican products (e.g., tequila, tortilla, and diverse Mexican chili sauces).

\section{Supplementary Information}

The online version contains supplementary material available at https://doi. org/10.1186/s42779-021-00111-6.

Additional file 1. Studies on investigating probiotics or prebiotics contained in pulque.

\section{Acknowledgements}

R. Castro-Muñoz acknowledges the School of Engineering and Science and the FEMSA Biotechnology Center at Tecnológico de Monterrey for their support through the Bioprocess (0020209113) Focus Group.

\section{Authors' contributions}

ZPGA compiled the literature and wrote the paper and RCM edited and contributed to writing the paper. All authors have read and agreed to the published version of the manuscript. Both authors read and approved the final manuscript.

\section{Funding}

This research received no external funding.

\section{Availability of data and materials}

All data and materials are publicly available and are cited in the text. Mentioned of products are for information only and does not imply recommendation by the authors.

\section{Declaration}

\section{Competing interests}

The authors declare no competing interests.

\section{Author details}

${ }^{1}$ Tecnologico de Monterrey, Campus Toluca, Avenida Eduardo Monroy Cárdenas 2000 San Antonio Buenavista, 50110 Toluca, Mexico. ${ }^{2}$ Department of Process Engineering and Chemical Technology, Faculty of Chemistry, Gdansk University of Technology, 11/12 Narutowicza St., 80-233 Gdańsk, Poland.

\section{Received: 30 October 2020 Accepted: 18 November 2021}

Published online: 29 November 2021

\section{References}

1. Hui Y, Evranuz E, Escalante A, Giles-Gómez M, Flores G, Acuña V, et al. Pulque fermentation. In: Hui Y, Evranuz E, editors., et al., Handbook of plant-based fermented food and beverage technology. 2nd ed. Boca Raton: CRC Press; 2012. p. 691-706. https://doi.org/10.1201/b12055-50.

2. Walter Hough B. The pulque of Mexico. In: The agaves flourish in the warm southwestern portions of the proceedings of United States National Museum, vol XXXIII; 1904. p. 85-92.

3. Rojas-Rivas E, Viesca González FC, Espeitx Bernat E, Quintero Salazar B. El maguey, el pulque y las pulquerías de Toluca, Estado de México, ¿patrimonio gastronómico turístico? PASOS Rev Tur y Patrim Cult. 2016;14:1199-215. https://doi.org/10.25145/j.pasos.2016.14.080.

4. Escalante A, López Soto DR, Velázquez Gutiérrez JE, Giles-Gómez M, Bolívar F, López-Munguía A. Pulque, a traditional Mexican alcoholic fermented beverage: historical, microbiological, and technical aspects. Front Microbiol. 2016;7:1-18. https://doi.org/10.3389/fmicb.2016.01026.
5. Álvarez-Ríos GD, Pacheco-Torres F, Figueredo-Urbina CJ, Casas A. Management, morphological and genetic diversity of domesticated agaves in Michoacán, México. J Ethnobiol Ethnomed. 2020;16:3. https://doi. org/10.1186/s13002-020-0353-9.

6. Trade TP, Colonial L, Source JEK. The pulque trade of late colonial Mexico City, vol. 37. Cambidge: Cambidge University Press; 1980. p. 193-221. https://doi.org/10.2307/981061.

7. Kasiak NR. Fermenting identities: race and pulque politics in Mexico City between 1519 and 1754. Richmond: Eastern Kentucky University; 2012

8. Valadez-Blanco R, Bravo-Villa G, Santos-Sánchez NF, Velasco-Almendarez SI, Montville TJ. The artisanal production of pulque, a traditiona beverage of the Mexican Highlands. Probiotics Antimicrob Proteins. 2012;4:140-4. https://doi.org/10.1007/s12602-012-9096-9.

9. García-Herrera EJ, Méndez-Gallegos SJ, Talavera-Magaña D. El genero Agave spp. en México: principales usos de importancia socioeconómica y agroecológica. Rev Salud Pública y Nutr Edición Espec 2010;5:109-29.

10. Trejo L, Reyes M, Cortés-Toto D, Romano-Grande E, Muñoz-Camacho LL. Morphological diversity and genetic relationships in pulque production agaves in Tlaxcala, Mexico, by means of unsupervised learning and gene sequencing analysis. Front Plant Sci. 2020;11:1-14. https://doi.org/10. 3389/fpls.2020.524812.

11. Mohar Betancourt L, Fernández DR. El estudio de los códices. Desacatos Rev Ciencias Soc. 2006;22:9-36.

12. Gonçalves De Lima O. El maguey y el pulque en los códices. Mexico: Fondo de Cultura Económica; 1986.

13. Velasco Toro J. Cosmosvision y deidades prehispánicas de la tierra y el agua en los pueblos del Papaloapan veracruzano. La Palabra y El Hombre. 2004;25:41-64.

14. Kampen ME. Classic Veracruz grotesques and sacrificial iconography. Man New Ser. 1978;13:116-26.

15. López Austin A. Los mitos el Tlacuache. 4th ed. Albuquerque: University of New Mexico Press; 1988.

16. Toxqui Garay MA. "El Recreo de los Amigos". Mexico City's Pulquerias during the Liberal Republic (1856-1911). Tucson: University of Arizona; 2008.

17. Piccato P. "El Paso de Venus por el disco del sol": criminality and alcoholism in the Late Porfiriato. Mex Stud Mex. 1995;11:203-41. https://doi.org/ 10.2307/1051921

18. Ramírez RR. La representación popular del maguey y el pulque en las artes. Cuicuilco. 2007;14:115-49.

19. Valadez MM. Pulque limpio/pulque sucio: disputas en torno a la legitimidad y la producción social del valor. Rev Colomb Antropol. 2014;50:4163. https://doi.org/10.22380/2539472x46.

20. Ramírez R. El Maguey y el Pulque: Memoria y Tradición convertidas en Historia, 1884-1993. Mexico: Universidad Benemérita de Puebla; 2004.

21. Rojas-Rivas E, Cuffia F. Identifying consumers' profile and factors associated with the valorization of pulque: a traditional fermented beverage in Central Mexico. Food Sci Technol Int. 2020. https://doi.org/10.1177/10820 13220917554.

22. Blandino A, Al-Aseeri ME, Pandiella SS, Cantero D, Webb C. Cereal-based fermented foods and beverages. Food Res Int. 2003;36:527-43. https:// doi.org/10.1016/50963-9969(03)00009-7.

23. Lappe-Oliveras P, Moreno-Terrazas R, Arrizón-Gaviño J, Herrera-Suárez T, García-Mendoza A, Gschaedler-Mathis A. Yeasts associated with the production of Mexican alcoholic nondistilled and distilled Agave beverages. FEMS Yeast Res. 2008;8:1037-52. https://doi.org/10.1111/j.1567-1364. 2008.00430.x

24. Ramírez JF, Sánchez-Marroquín A, Álvarez MMVR. Industrialization of indigenous fermented foods. In: Steinkraus KE, editor. Industrialization of indigenous fermented foods, revised and expanded. Boca Raton: CRC Press; 2004. p. 548-75. https://doi.org/10.1201/9780203022047.

25. Gómez-Aldapa CA, Díaz-Cruz CA, Villarruel-LíPez A, Torres-Vitela MDR, Añorve-Morga J, Rangel-Vargas E, et al. Behavior of Salmonella typhimurium, Staphylococcus aureus, Listeria monocytogenes, and Shigella flexneri and Shigella sonnei during production of pulque, a traditional Mexican beverage. J Food Prot. 2011;74:580-7. https://doi.org/10.4315/0362-028X. JFP-10-382

26. Mesillas G, Castro PVB, Ordaz J, Zúñiga Juárez JB. Potencial Probiótico de Bacterias Aisladas del Pulque: Una Revisión. Investig y Desarro En Cienc y Tecnol Aliment. 2016:1:924-30. 
27. Romero-Luna HE, Hernández-Sánchez H, Dávila-Ortiz G. Traditional fermented beverages from Mexico as a potential probiotic source. Ann Microbiol. 2017;67:577-86. https://doi.org/10.1007/s13213-017-1290-2.

28. Steinkraus KH. Classification of fermented foods: worldwide review of household fermentation techniques. Food Control. 1997;8:311-7. https:// doi.org/10.1016/s0956-7135(97)00050-9.

29. Estrada-Godina AR, Cruz-Guerrero AE, Lappe P, Ulloa M, García-Garibay M, Gómez-Ruiz L. Isolation and identification of killer yeasts from Agave sap (aguamiel) and pulque. World J Microbiol Biotechnol. 2001;17:557-60. https://doi.org/10.1023/A:1012210106203.

30. Steinkraus KH. Bio-enrichment: production of vitamins in fermented foods. In: Wood BJB, editor. Microbiology of fermented foods. Boston: Springer; 1998. p. 603-21. https://doi.org/10.1007/978-1-4613-0309-1_19.

31. Escalante A, Giles-Gómez M, Hernández G, Córdova-Aguilar MS, LópezMunguía A, Gosset G, et al. Analysis of bacterial community during the fermentation of pulque, a traditional Mexican alcoholic beverage, using a polyphasic approach. Int J Food Microbiol. 2008;124:126-34. https://doi. org/10.1016/j.ijfoodmicro.2008.03.003.

32. Solórzano MCH. Identificación polifásica de levaduras y bacterias ácido lácticas aisladas de aguamiel, pulque y semilla. Ensenada: CENTRO DE INVESTIGACIÓN CIENTÍFICA Y DE EDUCACIÓNSUPERIOR DE ENSENADA; 2008.

33. Gutiérrez-Uribe JA, Figueroa LM, Martín-del-Campo ST, Escalante A. Pulque. Amsterdam: Elsevier Inc.; 2017. https://doi.org/10.1016/B978-012-802309-9.00023-6.

34. Carbajal A. The United States Patent Office. 645520;1912.

35. Banco de Normas Mexicanas. NMX-V-037-1972. Pulque manejado a granel. Pulque handled in bulk. ColposMx 1978;3-6.

36. Castro-Muñoz R. Pervaporation-based membrane processes for the production of non-alcoholic beverages. J Food Sci Technol. 2019;56:2333-44. https://doi.org/10.1007/s13197-019-03751-4

37. Backstrand JR, Allen LH, Martinez E, Pelto GH. Maternal consumption of pulque, a traditional central Mexican alcoholic beverage: relationships to infant growth and development. Public Health Nutr. 2001;4:883-91. https://doi.org/10.1079/phn2001130.

38. Correa-Ascencio M, Robertson IG, Cabrera-Cortés O, Cabrera-Castro R, Evershed RP. Pulque production from fermented agave sap as a dietary supplement in Prehispanic Mesoamerica. Proc Natl Acad Sci U S A. 2014;111:14223-8. https://doi.org/10.1073/pnas.1408339111.

39. Ortiz-Basurto RI, Pourcelly G, Doco T, Williams P, Dormer M, Belleville MP. Analysis of the main components of the aguamiel produced by the maguey-pulquero (Agave mapisaga) throughout the harvest period. J Agric Food Chem. 2008;56:3682-7. https://doi.org/10.1021/jf072767h.

40. Cervantes-Elizarrarás A, del Cruz-Cansino NS, Ramírez-Moreno E, Vega-Sánchez V, Velázquez-Guadarrama N, Zafra-Rojas QY, et al. In vitro probiotic potential of lactic acid bacteria isolated from aguamiel and pulque and antibacterial activity against pathogens. Appl Sci. 2019;9:1-11. https://doi.org/10.3390/app9030601.

41. Castro-Rodriguez D, Hernández Sánchez H, Yáñez FJ. Probiotic properties of Leuconostoc mesenteroides isolated from aguamiel of Agave salmiana. Probiotics Antimicrob Proteins. 2015;7:107-17. https://doi.org/10.1007/ s12602-015-9187-5.

42. Fooks LJ, Fuller R, Gibson GR. Prebiotics, probiotics and human gut microbiology. Int Dairy J. 1999;9:53-61. https://doi.org/10.1016/S0958-6946(99) 00044-8.

43. World Health Organization F and AO of the UN. Guidelines for the evaluation of probiotics in food. Geneva: WHO; 2002.

44. Correia MITD, Liboredo JC, Consoli MLD. The role of probiotics in gastrointestinal surgery. Nutrition. 2012;28:230-4. https://doi.org/10.1016/j.nut. 2011.10.013.

45. Torres-Maravilla E, Lenoir M, Mayorga-Reyes L, Allain T, Sokol H, Langella $P$, et al. Identification of novel anti-inflammatory probiotic strains isolated from pulque. Appl Microbiol Biotechnol. 2016;100:385-96. https://doi. org/10.1007/s00253-015-7049-4

46. Neef A, Sanz Y. Future for probiotic science in functional food and dietary supplement development. Curr Opin Clin Nutr Metab Care. 2013;16:679_ 87. https://doi.org/10.1097/MCO.0b013e328365c258.

47. Castro-Zavala A, Juárez-Flores BI, Pinos-Rodríguez JM, Delgado-Portales RE, Aguirre-Rivera JR, Alcocer-Gouyonnet F. Prebiotic effects of Agave salmiana fructans in Lactobacillus acidophilus and Bifidobacterium lactis cultures. Nat Prod Commun. 2015;10:1985-8. https://doi.org/10.1177/ $1934578 \times 1501001145$.

48. Gibson GR, Probert HM, Van LJ, Rastall RA, Roberfroid MB. Dietary modulation of the human colonic microbiota: updating the concept of prebiotics. Nutr Res Rev. 2004;17:259-75. https://doi.org/10.1079/nrr20 0479

49. González-Vázquez R, Mayorga-Reyes L, Monroy-López A, Reyes-Nava LA, Rivera-Espinoza Y, Azaola-Espinosa A. Antibiotic resistance and tolerance to simulated gastrointestinal conditions of eight hemolytic Bacillus pumilus isolated from pulque, a traditional Mexican beverage. Food Sci Biotechnol. 2017;26:447-52. https://doi.org/10.1007/s10068-017-0061-y.

50. Gómez-Aldapa CA, Díaz-Cruz CA, Villarruel-López A, Del Refugio T-V, Rangel-Vargas E, Castro-Rosas J. Acid and alcohol tolerance of Escherichia coli O157:H7 in pulque, a typical Mexican beverage. Int J Food Microbiol. 2012;154:79-84. https://doi.org/10.1016/j.ijfoodmicro.2011.12.027.

51. Blas-Yañez S, Thomé-Ortiz H, Vizcarra-Bordi I, Espinoza-Ortega A. Street sale of pulque and sociospatial practices: a gender perspective in central Mexico. J Ethn Foods. 2018;5:311-6. https://doi.org/10.1016/j.jef.2018.10. 005.

52. Alcántara-Zavala AE, de Figueroa-Cárdenas JD, Morales-Sánchez E, Aldrete-Tapia JA, Arvizu-Medrano SM, Martínez-Flores HE. Application of ohmic heating to extend shelf life and retain the physicochemical, microbiological, and sensory properties of pulque. Food Bioprod Process. 2019;118:139-48. https://doi.org/10.1016/j.fbp.2019.09.007.

53. Kataria TK, Sosa-Morales ME, Olvera-Cervantes JL, Rojas-Laguna R, Corona-Chavez A. Dielectric properties of pulque at different temperatures from 0.1 to $25 \mathrm{GHz}$. J Microw Power Electromagn Energy. 2019;53:215-24. https://doi.org/10.1080/08327823.2019.1677432.

54. Zielińska D, Kolozyn-Krajewska D, Laranjo M. Food-origin lactic acid bacteria may exhibit probiotic properties: review. Biomed Res Int. 2018;2018:1-15. https://doi.org/10.1155/2018/5063185.

55. Riveros-Mckay F, Campos I, Giles-Gómez M, Bolívar F, Escalante A. Draft genome sequence of Leuconostoc mesenteroides P45 isolated from pulque, a traditional Mexican alcoholic fermented beverage. Genome Announc. 2014;2:730-1. https://doi.org/10.1128/genomeA.01130-14.

56. Allais JJ, Hoyos-Lopez G, Kammoun S, Baratti JC. Isolation and characterization of thermophilic bacterial strains with inulinase activity. Appl Environ Microbiol. 1987;53:942-5. https://doi.org/10.1128/aem.53.5.942945.1987.

57. Cruz-Guerrero AE, Olvera JL, García-Garibay M, Gómez-Ruiz L. Inulinasehyperproducing strains of Kluyveromyces sp. isolated from aguamiel (Agave sap) and pulque. World J Microbiol Biotechnol. 2006;22:115-7. https://doi.org/10.1007/s11274-005-9005-4.

58. Hernández-López Z, Rangel-Vargas E, Castro-Rosas J, Gómez-Aldapa CA, Cadena-Ramírez A, Acevedo-Sandoval OA, et al. Optimization of a spraydrying process for the production of maximally viable microencapsulated Lactobacillus pentosus using a mixture of starch-pulque as wall material. Lwt. 2018;95:216-22. https://doi.org/10.1016/j.lwt.2018.04.075.

59. Castro-Muñoz R, Barragán-Huerta BE, Yáñez-Fernández J. Use of gelatin-maltodextrin composite as an encapsulation support for clarified juice from purple cactus pear (Opuntia stricta). LWT Food Sci Technol. 2015;62:242-8. https://doi.org/10.1016/j.lwt.2014.09.042.

60. Castro-Muñoz R, Nieves-Segura N. Sorption isotherms and isosteric heat estimation of purple cactus pear (Opuntia stricta) juice embedded in gelatin-maltodextrin matrix. J Food Process Eng. 2018;41:1-7. https://doi. org/10.1111/jfpe.12848

61. Torres-Maravilla E, Alejandra Blancas-Nápoles J, Alberto VázquezLandaverde P, Cristiani-Urbina E, Mayorga-Reyes L, Elena S-P. Evaluación de sedimentos de pulque (Xaxtle) como cultivo iniciador para obtener un producto de panificación de bajo índice glucémico. Agrociencia. 2016;50:183-200

62. Vernon-Carter EJ, Garcia-Diaz S, Reyes I, Carrillo-Navas H, Alvarez-Ramirez J. Rheological and thermal properties of dough and textural and microstructural characteristics of bread with pulque as leavening agent. Int J Gastron Food Sci. 2017;9:39-48. https://doi.org/10.1016/j.ijgfs.2017.03. 001.

63. Tovar LR, Olivos M, Gutierrez ME. Pulque, an alcoholic drink from rural Mexico, contains phytase. Its in vitro effects on corn tortilla. Plant Foods Hum Nutr. 2008;63:189-94. https://doi.org/10.1007/s11130-008-0089-5.

64. Castro-Muñoz R, Boczkaj G, Gontarek E, Cassano A, Fíla V. Membrane technologies assisting plant-based and agro-food by-products processing: a 
comprehensive review. Trends Food Sci Technol. 2020;95:219-32. https:// doi.org/10.1016/j.tifs.2019.12.003.

65. Sultan MT, Haque MMU, Maniruzzaman M, Alam MA. Composites of

polypropylene with pulque fibres: morphology, thermal and mechanical properties. J Thermoplast Compos Mater. 2015;28:1615-26. https://doi. org/10.1177/0892705713513295.

\section{Publisher's Note}

Springer Nature remains neutral with regard to jurisdictional claims in published maps and institutional affiliations.

- fast, convenient online submission

- thorough peer review by experienced researchers in your field

- rapid publication on acceptance

- support for research data, including large and complex data types

- gold Open Access which fosters wider collaboration and increased citations

- maximum visibility for your research: over $100 \mathrm{M}$ website views per year

At BMC, research is always in progress.

Learn more biomedcentral.com/submissions 